\title{
OECD/DAC 원조효과작업반 집행위원회
}

\section{I. 회의개요}

- $\mathrm{OECD} \mathrm{DAC}$ 원조효과작업반 집행위원회가 2011.3.9 10 OECD 본부(파리)에서 개최되어 기존 원조효과성 논의의 범위를 한층 넓히고자 하는 합의가 이루어진 바, 이 내용을 아래에 정리함.

\section{II. 주요내용}

- 금번 집행위에서는 HLF-4 논의 주제를 기존 원조효과성 논의에 그치지 않고 보다 넓은 맥락의 개발효과성으로 확대한다는 데 전반적인 합의가 이루어짐.

- HLF-4에 대한 정치적 관심 및 이해제고 위한 구체적인 outreach계획 등이 논의되면서, HLF-4 의 정치적 참여 및 위상 제고를 위한 모멘텀이 형성됨.

- HLF-4의 핵심 주제 및 결과 문서 outline의 구성 요소가 도출되고, 행사 준비를 위한 core group의 활동계획이 확정되면서 $\mathrm{HLF}-4$ 준비과정이 본격화됨.

- HLF-4 주최국이자 작업반 부의장국으로서 $\mathrm{HLF}-4$ 주제설정 등 실질사항 논의에 적극 참여하 고, 행사준비회의를 주재하는 한편, $\mathrm{DAC}$ 의장, 원조효과작업반 의장단 등 주요인사들과의 협의를 통해 '원조효과성에서 개발효과성으로의 논의확대' 관련 우리 입장에 대한 지지 및 협력기반을 마련함. 